\title{
Metajornalismo - Quando o jornalismo é sujeito do próprio discurso. Madalena Oliveira, Grácio Editor: Coimbra, 2010, 300 pp.
}

Rita Araújo*

Num livro que resulta essencialmente da tese de doutoramento apresentada pela investigadora em 2007, Madalena Oliveira dá-nos conta da possibilidade de o jornalismo reflectir sobre o próprio jornalismo. Nas palavras da autora, a obra "visa fundamentar a experiência metajornalística como uma prática adjuvante da cidadania" (Oliveira, 2010: 32). Referindo que em Portugal não há ainda uma tradição metajornalística, afirma que começa agora a formar-se a consciência de que é importante debater o papel dos média e os efeitos da informação (idem: 20). "Conquanto tenha inimigos ferozes dentro do próprio meio jornalístico, o metajornalismo terá, pelo menos, a virtude de desmistificar a profissão aos olhos do público" (idem: 30), refere Madalena Oliveira neste trabalho.

Com prefácio de Moisés de Lemos Martins, a obra encontra-se dividida em três partes. A segunda parte - "Do triunfo do jornalismo ao embaraço dos jornalistas" -, que servirá de texto-âncora a esta crítica, compõe-se de três capítulos (pp. 115-195): “Um métier ferido pela escrita dos dias" (pp. 119-129), “O jornalismo como archote ou ainda a ideia de poder" (pp. 143-168) e "Da fragilidade de ser jornalista” (pp. 173-188).

A autora discorre, assim, sobre o "desprestígio dos jornalistas", encontrando, em parte, em alguma literatura da segunda metade do século XIX os primeiros sinais deste descrédito (idem: 117). Cita Karl Kraus e a sua visão derrotista da imprensa, em que o autor associa o jornalismo à impunidade e irresponsabilidade (idem: 118), sendo, no entanto, um dos escritores que mais se dedicou ao estudo e escrita do jornalismo. Madalena Oliveira refere que desde os primórdios da imprensa que o jornalismo é, de algum modo, mal visto pela sociedade; correspondendo a subleituras, os jornais foram, para muitos intelectuais, encarados como uma literatura menor dentro do mundo das letras. Foram vários os escritores que, ao longo dos anos, não pouparam críticas ao jornalismo e aos próprios jornalistas - críticas aos interesses que comandam os jornalistas, à pressão que exercem na sociedade, às conveniências e metamorfoses. A investigadora reporta mesmo relatos que se referem a um "jornalismo de metamorfoses, sem convicções, sem princípios e sem escrúpulos".

A autora é de opinião de que as preocupações de Kraus em relação ao futuro do jornalismo, na transição para o século XX, são muito actuais. Os média assistem a uma invasão da publicidade e à dependência económica e formação de impérios mediáticos, numa constante ameaça do pluralismo e da liberdade de imprensa. Na página 125, a

\footnotetext{
* Centro de Estudos de Comunicação e Sociedade (rita.manso.araujo@gmail.com).
} 
autora escreve: “Adoptando um tom e uma terminologia apocalípticos, Kraus insistiria mesmo que a independência económica e financeira seria, em matéria de imprensa, a condição sine qua non da independência moral e intelectual." A dependência económica, muito falada por Kraus, é um tópico assinalado por outros autores, nomeadamente Pierre Bourdieu e Serge Halimi. Bourdieu, em Sobre a Televisão, alude a um campo jornalístico definido por "relações de força completamente invisíveis", que só podem ser apreendidas através de indicadores económicos (Bourdieu, 1997: 40). O autor refere, então, um campo muito dependente de forças externas, com lutas arbitradas pelos níveis de audiência.

Mais do que reflectir a realidade, é preciso reconhecer hoje a capacidade dos média para a "fabricar" (Oliveira, 2010: 169). O jornalista constrói a realidade e o jornalismo torna-se "acima de tudo um poder constituinte da actualidade" (idem: 170). A chamada "teoria do espelho" - segundo a qual as notícias apenas reflectem o mundo exterior, sendo os jornalistas meros mediadores entre acontecimento e notícia - tem vindo a ser refutada, refere a autora, por algumas teorias do jornalismo, nomeadamente as teorias do gatekeeping e do agenda-setting. Aqui surgem também dois conceitos essenciais para a compreensão do jornalismo: aceitabilidade e legitimidade. Madalena Oliveira refere que é no público "que reside não só a fonte de legitimação como também a confirmação da aceitabilidade do jornalismo e dos jornalistas” (idem: 149). São também estes conceitos que contribuem para a ideia de poder associada ao jornalismo. Pegando na trilogia de poderes de Montesquieu, vários autores consideram o jornalismo como o "quarto poder"; outros preferem atribuir-lhe o carácter de "contrapoder".

As teorias do agenda-setting, gatekeeping e newsmaking contribuem, também elas, para a atribuição de poder ao jornalismo. O gatekeeping assume-se como a consciência de que nem tudo o que acontece tem espaço nos média, é o "poder para decidir o que ganha visibilidade noticiosa" (idem: 167). Este poder segue alguns critérios, que diferem consoante os autores. Pode dizer-se que o gatekeeping é a primeira etapa do newsmaking. O conceito de newsmaking tem que ver com noticiabilidade, referindo-se à elaboração e apresentação da notícia. Por fim, a teoria do agenda-setting diz respeito ao estabelecimento de uma opinião pública, à definição do papel dos média nesse processo e à discussão acerca da influência da agenda mediática. Estas teorias são fundamentais para perceber o jornalismo, mas não são suficientes, segundo a autora, para entender o poder do jornalismo. "Como repensar as questões do poder, da legitimidade e do reconhecimento dos jornalistas no contexto de novos media emergentes daquilo que poderíamos chamar a emancipação do cidadão?" (idem: 168). Esta questão afigura-se como fulcral no panorama jornalístico actual, visto que as teorias que conhecemos centram-se fundamentalmente num jornalismo pré-digital. Madalena Oliveira defende que é na passagem do jornalismo pré-digital ao pós-digital (fase na qual nos encontramos) que reside a renovação do debate sobre o poder do jornalismo. Deste modo, o que é actualmente distintivo do poder dos jornalistas? Numa época em que os cidadãos têm acesso à produção e distribuição de conteúdos noticiosos, através das novas tecnologias, como diferenciar o poder dos jornalistas? Como defender uma actividade que já não é mais exclusiva da profissão de jornalista? 
É conhecida a teoria de Noelle-Neumann da "espiral do silêncio", em que a autora refere um jogo entre opiniões maioritárias e minoritárias. Ao aperceberem-se de que têm uma opinião minoritária, as pessoas retraem-se, ainda que mantenham o que pensam. Temendo ficar numa posição de isolamento, as pessoas tendem a não exprimir o seu ponto de vista quando sabem que é contrário ao da opinião pública dominante. Noelle-Neumann defende, assim, que os média aceleram o silenciamento das minorias, influenciando a opinião pública e formando opiniões. Embora a informação seja um direito inalienável a qualquer cidadão, o jornalista estabelece uma espécie de contrato com o público (Bernier fala mesmo num “contrato social”), pressupondo-se ainda que a informação levada pelo jornalista ao cidadão tem uma determinada relevância social, o chamado interesse público. Este interesse público é um interesse maior, subentende um imperativo de utilidade geral (idem: 173) e não pode ser apenas a soma de interesses individuais. Dominique Wolton argumenta que "é preciso que o público possa distinguir rapidamente a informação certificada pelos profissionais, os jornalistas da informação, daquela que é produzida e distribuída por todos aqueles que têm acesso à Internet” (Wolton, 2003: 14 cit. in Oliveira, 2010: 188). As novas tecnologias promovem um maior acesso às fontes primárias de informação, pelo que assistimos actualmente a um fenómeno que é já apelidado de “jornalismo do cidadão”, em que o cidadão é produtor de conteúdos. Madalena Oliveira afirma que, "ainda que contribuindo para o alargamento dos canais de informação, o chamado jornalismo do cidadão parece contribuir ao mesmo tempo para a insustentável confusão entre informação importante e informação interessante" (Oliveira, 2010: 189). O jornalismo do cidadão carece de ética e identidade profissional, pode resultar de interesses privados (e não do interesse público) e não presta contas ao público.

A autora chega assim à conclusão de que a tecnologia é um "pau de dois bicos", encerrando em si novas oportunidades mas também novos desafios, quem sabe se traçando novos caminhos para a profissão de jornalista. Todos estes fenómenos sugerem uma mudança nesta profissão, obrigando a uma demarcação dos outros produtores de conteúdos noticiosos. O jornalismo vive talvez uma das suas maiores crises, em que por um lado há cada vez mais oferta de média e, por outro, mais concentração de grupos económicos; por um lado, há um dever de servir o interesse público e, por outro, o dever de gerar lucro. Madalena Oliveira fala num jornalismo "refém de uma cultura mercantil” (idem: 180) e em jornalistas “prisioneiros do público" (idem: 182). O jornalista é uma parte muito importante no processo de "fabrico" das notícias. No entanto, enfrenta cada vez mais dificuldades, ao nível da relação com as fontes e os seus interesses, dos valores ideológicos da empresa que integra, dos imperativos de mercado e ainda da pressão temporal (que se prende com as novas tecnologias e o imediatismo das mesmas), para citar alguns exemplos. As pressões económicas, a saturação do mercado e a precariedade da profissão são uma realidade. A ideia principal é a de que urge uma mudança no paradigma da profissão, que Madalena Oliveira sugere passar por uma aposta no discurso metajornalístico, isto é, na possibilidade de o jornalismo e os jornalistas também se sujeitarem ao escrutínio público que os caracteriza como agentes definidores da actualidade. 